\title{
Isotopic biomonitoring of anthropic carbon emissions in a megalopolis
}

\author{
Edison Armando Díaz-Álvarez ${ }^{1}$, Erick de la Barrera ${ }^{\text {Corresp. } 2}$ \\ 1 Instituto de Investigaciones Forestales, Universidad Veracruzana, Xalapa, Veracruz, Mexico \\ 2 Instituto de Investigaciones en Ecosistemas y Sustentabilidad, Universidad Nacional Autónoma de México, Morelia, Michoacán, Mexico \\ Corresponding Author: Erick de la Barrera \\ Email address: delabarrera@unam.mx
}

Atmospheric pollution has become a serious threat for human health and the environment. However, the deployment, operation, and maintenance of monitoring networks can represent a high cost for local governments. In certain locations, the use of naturally occurring plants for monitoring pollution can be a useful supplement of existing monitoring networks, and even provide information when other types of monitoring are lacking. In this work, we i) determined the tissue carbon content and the $\delta^{13} \mathrm{C}$ values for the epiphytic CAM bromeliad Tillandsia recurvata and the relationship of both parameters with the existing CO concentrations in the Valley of Mexico basin, and ii) mapped the spatial distribution of such elemental and isotopic composition for this plant within the basin, in order to assess its potential as an atmospheric biomonitor of carbon monoxide, a pollutant with important repercussions on public health. The $\mathrm{CO}$ concentrations in the basin ranged from $0.41 \mathrm{ppm}$ at rural locations to $0.81 \mathrm{ppm}$ at urban sites. The carbon content of $T$. recurvata which averaged $42.9 \pm 0.34 \%$ (dry weight), was not influenced by the surrounding $\mathrm{CO}$ concentration. In contrast, the $\delta^{13} \mathrm{C}$ depended on the sites where the plants were collected. For example, the values were $-13.21 \%$ in rural areas and as low as $-17.47 \%$ in an urban site. Indeed, the isotopic values had a positive linear relationship with the atmospheric $\mathrm{CO}$ concentrations. Given the close relationship observed between the isotopic composition of $T$. recurvata with the CO concentrations in the Valley of Mexico, the $\delta^{13} \mathrm{C}$ values can be useful for the detection of atmospheric carbonaceous emissions. 


\title{
2 Isotopic biomonitoring of anthropic carbon emissions
} 3 in a megalopolis

4

5

6

7

8 9

\author{
Edison A. Díaz-Álvarez ${ }^{1}$ Erick de la Barrera ${ }^{2}$ \\ ${ }^{1}$ Instituto de Investigaciones Forestales, Universidad Veracruzana, Xalapa, Veracruz 91070, \\ Mexico \\ ${ }^{2}$ Instituto de Investigaciones en Ecosistemas y Sustentabilidad, Universidad Nacional Autónoma \\ de México, Morelia, Michoacán 58190, Mexico
}

Corresponding Author:

Erick de la Barrera ${ }^{2}$

Antigua Carretera a Pátzcuaro 8701, Morelia, Michoacán 58190, Mexico

Email address: delabarrera@unam.mx

\section{Abstract}

Atmospheric pollution has become a serious threat for human health and the environment. However, the deployment, operation, and maintenance of monitoring networks can represent a high cost for local governments. In certain locations, the use of naturally occurring plants for monitoring pollution can be a useful supplement of existing monitoring networks, and even provide information when other types of monitoring are lacking. In this work, we i) determined the tissue carbon content and the $\delta^{13} \mathrm{C}$ values for the epiphytic CAM bromeliad Tillandsia recurvata and the relationship of both parameters with the existing CO concentrations in the Valley of Mexico basin, and ii) mapped the spatial distribution of such elemental and isotopic composition for this plant within the basin, in order to assess its potential as an atmospheric biomonitor of carbon monoxide, a pollutant with important repercussions on public health. The CO concentrations in the basin ranged from $0.41 \mathrm{ppm}$ at rural locations to $0.81 \mathrm{ppm}$ at urban sites. The carbon content of $T$. recurvata which averaged $42.9 \pm 0.34 \%$ (dry weight), was not influenced by the surrounding $\mathrm{CO}$ concentration. In contrast, the $\delta^{13} \mathrm{C}$ depended on the sites where the plants were collected. For example, the values were $-13.21 \%$ in rural areas and as low as $-17.47 \%$ in an urban site. Indeed, the isotopic values had a positive linear relationship with the atmospheric CO concentrations. Given the close relationship observed between the isotopic composition of T. recurvata with the CO concentrations in the Valley of Mexico, the $\delta^{13} \mathrm{C}$ values can be useful for the detection of atmospheric carbonaceous emissions. 


\section{Introduction}

38 Atmospheric pollution has become a serious threat for human health and the environment. This is

39 especially worrying for populous cities, which is a frequent case throughout Latin America (Kampa \&

40 Castanas, 2008; Rioja-Rodríguez et al., 2016). For example, Mexico City, with vigorous industrial and

41 household activities, as well as numerous motor vehicles of all classes, has seen an increase of emissions

42 of different pollutants to the atmosphere. This has resulted in a higher incidence of respiratory and

43 cardiovascular diseases, which already cause at least 9,600 premature deaths annually just in this

44 - megalopolis and 20,000 in the whole country (Stevens et al., 2008; INEGI, 2011). In addition,

45 atmospheric pollution is one of the leading causes of biodiversity loss and ecosystem change both, from

46 nitrogen deposition and the release of greenhouse gas emissions (Sala et al., 2000; Rockström et al., 2009;

47 Hooper et al., 2012).

48 Carbon monoxide (CO) is among the main atmospheric pollutants with public health

49 repercussions. Not only can acute exposure to high concentrations of CO lead to death, but the chronic

50 exposure to low concentrations of this gas has been associated with cardiovascular and neurological

51 damage (WHO, 1999; Townsend \& Maynard, 2002; Prockop, 2005; Chen et al., 2007). CO results from

52 the combustion of carbonaceous fuels, which also produces carbon dioxide. The proportion in which they

53 are emitted depends on the quality of the combustion. For example, if a motor works in optimal

54 conditions, i.e., when the mixture of air, fuel, and temperature inside an automobile engine is ideal, a

55 complete combustion of the fuel is achieved, resulting in a complete oxidation of carbon and the

56 subsequent emission of $\mathrm{CO}_{2}$, predominantly. For example, 3.8 liters of gasoline, whose weight is 2.7

57 kilograms, can emit 9 kilograms of $\mathrm{CO}_{2}$ and ideally very low or insignificant amounts of $\mathrm{CO}$ (Salameh,

58 2014). Nevertheless, when the engine conditions are not optimal, an incomplete combustion/oxidation

59 generates higher emissions of $\mathrm{CO}$; this generally occurs in the engines of old cars and during heavy traffic

60 congestions, which are frequent in the Valley of Mexico, where the vehicular fleet commonly exceeds 20

61 years of operation (Williams, 1990; Turnbull et al., 2011a; Silva et al., 2013; Salameh, 2014; SEDEMA,

62 2016a).

Peer) reviewing PDF | (2019:10:41903:2:1:NEW 29 Apr 2020) 
64 atmospheric pollution, is thus imperative, including the monitoring of carbon emissions. However, the 65 deployment, operation and maintenance of monitoring networks can represent high costs that in some cases exceed the budget and priorities of the local governments (Díaz-Álvarez et al., 2019). For example, only 77 cities from 17 countries in Latin America and the Caribbean have public information about atmospheric pollution, while 16 countries in the region do not release data at all (Rioja-Rodriguez et al., 2016). In Mexico, federal environmental and health regulations mandate the deployment of air quality monitoring networks for cities whose population exceeds half a million and for settlements with emissions surpassing 20,000 tons of regulated pollutants per year (SEMARNAT, 2012). However, as it occurs all over Latin America and the Caribbean, the monitoring of air quality is not evaluated in many localities as required (Rioja-Rodriguez et al., 2016; Instituto Nacional de Ecología y Cambio Climático, 74 2017).

The use of naturally occurring plants as biomonitors can supplement existing air quality monitoring systems and in some cases, when a monitoring system is lacking, be utilized for the early detection of increasing atmospheric pollution, considering that the elemental and isotopic composition of plant tissues can respond to the concentration of some pollutants (Díaz-Álvarez et al. 2018, 2020). Once the origin and concentration of the pollution is determined, reduction and mitigation actions can be implemented. A particularly suitable group of plants for biomonitoring are those that depend exclusively from atmospheric sources for their mineral nutrition, commonly named "atmospheric plants" (Markert et al. 2003; Vianna et al. 2011; Pellegrini et al. 2014; Díaz-Álvarez \& de la Barrera 2018; Díaz-Álvarez et al. 2018). One of such species is Tillandsia recurvata (L.) L (Schmitt et al., 1989). This CAM bromeliad is distributed from the southern

85 United States to Argentina and Chile, and it is commonly found growing on different built structures in 86 cities (Schrimpff, 1984; Díaz-Álvarez \& de la Barrera 2018). Additionally, the plant can remain 87 physiologically active year-round and, thanks to its absorptive trichomes, carry out bioaccumulation of 
88 different atmospheric pollutants including heavy metals, polycyclic aromatic hydrocarbons, nitrogen,

89 sulfur, and carbon (Schrimpff, 1984; Zambrano et al., 2009; Castañeda et al., 2016; Díaz-Álvarez \& de la

90 Barrera 2018: Piazzetta et al. 2018). Although, the carbon isotopic composition of this plant has been

91 reported for polluted and non-polluted sites, this is the first time that a specific relationship between

92 carbon emissions and the plant's responses is determined.

93 By means of an extensive sampling throughout the Valley of Mexico, we i) determined the carbon

94 content and the $\delta^{13} \mathrm{C}$ values for the epiphytic CAM bromeliad Tillandsia recurvata and their relationship

95 with the prevailing $\mathrm{CO}$ concentrations, and ii) mapped the spatial distribution of such elemental and

96 isotopic composition of this plant in the basin, in order to assess the potential that this plant has as an

97 atmospheric biomonitor of carbon monoxide.

98

99

100

101

102

103

104

105

106

107

108

109

110

111

112

113

\section{Materials \& Methods}

\section{Study region}

The study was conducted in the Valley of Mexico basin which covers an area of $7500 \mathrm{~km}^{2}$, with a mean elevation of $2240 \mathrm{~m}$, and a mean annual precipitation of $600 \mathrm{~mm}$ that can reach up to $1300 \mathrm{~mm}$ in the surrounding mountains at $5400 \mathrm{~m}$ (Fig. 1; Calderon and Rzedowski, 2001; SMN, 2016). The basin includes portions of the states of Hidalgo, Mexico, and Mexico City. Pachuca, the capital of Hidalgo, at the north has a population of 3 million. At the southern portion of the Valley sits Mexico City, whose population reaches 20 million. Additionally, various small towns and settlements with industrial or agricultural activities contribute to the 30 million inhabitants of the basin (INEGI, 2011; Díaz-Álvarez \& de la Barrera 2018).

\section{Atmospheric CO concentration and biomonitoring}

The Mexico City environmental authority has deployed an Automatic Atmospheric Monitoring Network (http://www.aire.cdmx.gob.mx/default.php) comprised of 33 stations, which monitor different parameters, 
114 including wet $\mathrm{N}$ deposition, $\mathrm{O}_{3}, \mathrm{NOx}, \mathrm{NO}_{2}, \mathrm{NO}, \mathrm{PM}_{10} \mathrm{PM}_{2.5}$ and $\mathrm{CO}$ (Fig. 1). We calculated the mean 115 concentration of CO (ppm) between January and November 2014 for each one of the 21 stations that 116 recorded this parameter during 2014.

117 We determined the relationship between CO concentrations in the Valley of Mexico and the 118 carbon content and the $\delta^{13} \mathrm{C}$ values was determined for the epiphytic CAM bromeliad Tillandsia 119 recurvata, which has an ample distribution in the Americas. This plant has been utilized as a biomonitor 120 of atmospheric pollution and can be easily found in the Valley of Mexico (Zambrano et al., 2009; Díaz121 Álvarez et al., 2018; Díaz-Álvarez \& de la Barrera, 2018; Piazzetta et al., 2018). Sampling sites were 122 determined in two steps. First, potential sites for the occurrence of T. recurvata were identified utilizing 123 Google Earth's satellite scenes, followed by a corroboration by means of the StreetView function where 124 available. In particular, we identified the presence of natural protected areas, vegetation stands in 125 rural/agricultural areas, or parks and other vegetated features in urban areas, where trees and shrubs that 126 could act as phorophytes for T. recurvata were be present. A total of 73 sites were identified within the 127 basin. Second, a stratified sampling (within the identified vegetated sites; Wang et al. 2012) was 128 conducted on 3-15 November 2014, which occurred towards the end of the rainy season, late in the 129 growing period for T. recurvata. After discarding those sites where T. recurvata was not found and those 130 where access was not possible, plant samples were collected for elemental and isotopic analyses from 22 131 sites (Fig. 1), including urban parks (7 sites), built urban structures (4 sites), agricultural sites (6 sites), 132 and natural protected areas (5 sites).

133 At each site, newly formed, fully developed leaves, which can be visually differentiated from 134 those that grew in previous years, were collected (Permit SGPA/DGGFS/712/2767/14, Secretaría de 135 Medio Ambiente y Recursos Naturales, Mexico) from 5 mature individuals growing at least $5 \mathrm{~m}$ apart 136 (Harmens et al., 2008; Díaz-Álvarez et al., 2019). The samples were dried at $60^{\circ} \mathrm{C}$ in a gravity convection 137 oven until reaching constant weight. Sample preparation for stable isotope analyses was conducted 138 following Díaz-Álvarez and de la Barrera (2018). The carbon isotope ratios, reported in parts per 
139 thousand were calculated relative to Vienna-Pee Dee Belemnite (VPDB). The analytical precision for the $140 \delta^{13} \mathrm{C}$ was $0.2 \pm 0.07 \%$ (SD). The natural abundances of ${ }^{13} \mathrm{C}$ were calculated as:

$$
\delta^{13} \mathrm{C}(\% \text { versus V-PDB })=\left(\mathrm{R}_{\text {sample }} / \mathrm{R}_{\text {standard }} 1\right) \times 1000
$$

142 where, $\mathrm{R}$ is the ratio of ${ }^{13} \mathrm{C} /{ }^{12} \mathrm{C}$ for carbon isotope abundance for a given sample (Ehlenringer and

143 Osmond, 1989; Evans, 2001).

144

145 Statistical and spatial analyses

146 Data were analyzed following Díaz-Álvarez \& de la Barrera (2018). In particular, linear regressions were

147 calculated to determine the relationship between CO concentrations and carbon content ( $\%$ dry weight),

148 as well as the isotopic composition ( $\delta^{13} \mathrm{C}$ values) for Tillandsia recurvata in the Valley of Mexico. The

149 differences between sites for the carbon content and the $\delta^{13} \mathrm{C}$ values were determined by means of the

150 Kruskal-Wallis one-way analysis of variance by ranks, followed by a Nemenyi's post-hoc tests for

151 pairwise multiple comparisons $(p \leq 0.05)$. The analyses were conducted using the Pairwise multiple

152 comparison of mean ranks package (PMCMR) in R (version 3.5.3, R Core Team, R foundation for

153 Statistical Computing, Vienna, Austria; Pohlert, 2014).

154 Data interpolation for CO concentration within Mexico City and for T. recurvata tissue carbon

155 content and $\partial^{13} \mathrm{C}$ values throughout the Valley of Mexico were conducted with the Ordinary Kriging

156 model contained in ArcGIS 10.5 (ESRI, Redlands, CA, USA), which was also utilized to create the maps.

157 This interpolation method is based on the assumption that data are spatially autocorrelated (Cressie, 1988;

158 Wang et al., 2002; Wong et al., 2004), which generally is the case for atmospheric pollutants, as their

159 concentration is higher with proximity to the source, thus influencing the ensuing plant responses

160 (Stevens et al., 2004; Díaz-Álvarez et al., 2018). This allows the estimation of parameters of interest in

161 relatively large geographical regions (Liao et al., 2017), where only a sparse sampling is available (Oliver

$162 \&$ Webster, 2014). While interpolation protocols have been developed that improve on Ordinary Kriging,

163 this model is among the most utilized methods in environmental studies, including those considering 
164 atmospheric pollution (Liao et al., 2017; Gupta et al., 2018; Gómez-Lozada et al., 2019; Huang et al., 165 2020).

166

\section{Results}

\section{Spatial distribution of CO concentrations}

169 The CO concentration, averaged $0.67 \pm 0.03 \mathrm{ppm}$ in Mexico City, where the monitoring network is 170 deployed (Fig. 2). The central and northern portions had the highest concentrations of CO, reaching a 171 maximum of $0.81 \mathrm{ppm}$, and the lowest concentration was found at the northeast end of the distribution of 172 the monitoring network, where it reached a mean value of $0.41 \mathrm{ppm}$ (Fig. 2).

173

174 Carbon content and isotopic composition for Tillandsia recurvata

175 On average, the tissue carbon content was $42.91 \pm 0.34 \%$ (dry weight) ranging from $38.43 \%$ for plants 176 collected in the urban area of a small town at the north-west portion of the Valley, to $44.92 \%$ at the 177 southern part of the Valley, in the middle of the Mexico City (Fig. 3A). However, the carbon content was 178 not affected by the CO concentration recorded during 2014 by the Mexico City monitoring network $\left(\mathrm{R}^{2}=\right.$ 179 0.015; Fig. 4A).

180 Contrasting with what occurred for the carbon content, the $\delta^{13} \mathrm{C}$ values responded positively to the 181 atmospheric $\mathrm{CO}$ concentration, being lower in sites with higher concentrations than in those with lower 182 CO concentrations (Fig. 4B; $\mathrm{R}^{2}=0.675$ ). For example, the $\delta^{13} \mathrm{C}$ values reached $-16.16 \%$ in Pachuca, a 183 populous city at the north of the Valley, which is lower than in some rural sites further south (Fig. 3B). 184 The $\delta^{13} \mathrm{C}$ values were as negative as $-17.47 \%$ for plants collected in an urban site where the mean $\mathrm{CO}$ 185 concentration averaged $0.70 \mathrm{ppm}$ during 2014 (Fig. 3B). In contrast, the highest $\delta^{13} \mathrm{C}$ values of $-13.21 \%$ o 186 were found for plants growing at the archeological site of Teotihuacan, whose CO concentration was the 187 lowest recorded inside the monitored area $(p<0.05$; Fig. 3B). 


\section{Discussion}

191 The atmospheric concentration of CO in the area covered by the monitoring network tended to be higher

192 in the vicinity of the numerous important and busy motorways that have been built in this region and are

193 utilized by the 5.2 million vehicles registered in Mexico City and its metropolitan area, in addition to

194 various thousands of visiting vehicles from other cities and states (SEDEMA 2016a). Indeed, motor

195 vehicles are the main source of $\mathrm{CO}$ for the region, contributing with $96 \%$ of the total emissions, which

196 amount to nearly 700 million tons just in Mexico City; the remaining 4\% originated from industrial and

197 domestic sources (SEDEMA, 2016b). However, it is worth mentioning that the CO concentrations of 3.8

198 ppm measured in Mexico City and its metropolitan area during this study did not exceed the Mexican

199 standard (exposure to 11 ppm for 8 hours) nor the World Health Organization's (9 ppm) and the United

200 States Environmental Protection Agency's criteria for this pollutant (9 ppm; WHO, 1999; SEMARNAT,

201 2012; SEDEMA, 2016a).

202

While the carbon content of $T$. recurvata was insensitive to the $\mathrm{CO}$ concentration, the $\partial^{13} \mathrm{C}$ of

203

204

205

206

207

208

209

210

211

212

213

214

newly formed leaves adequately biomonitored the prevailing atmospheric pollution, with values that were substantially more negative in polluted sites than in "clean" sites, a pattern that has been previously documented with atmospheric biomonitors (Martin, 1994; Lichtfouse et al., 2003; Zambrano et al., 2009;

Cobley \& Pataki, 2019). When interpreting the isotopic signature of carbon biomonitors it is important to consider that while $\mathrm{CO}$ is but a small fraction of the urban carbonaceous emissions, it is produced from combustion simultaneously with $\mathrm{CO}_{2}$, a gas that is usually not included in urban air quality monitoring protocols (SEMARNAT 2012; SEDEMA 2016b). Thus, the plants are in fact mostly recording the isotopic signal of $\mathrm{CO}_{2}$ assimilated by photosynthesis. However, the relationship between atmospheric $\mathrm{CO}$ and $\mathrm{CO}_{2}$ concentrations is usually linear, so that the "calibration" conducted in the present study utilizing $\mathrm{CO}$ (the only carbon gas that is monitored) as an integrative proxy for urban carbon emissions could be utilized in other unmonitored cities (Turnbull et al. 2011b; Silva et al. 2013; Gromov et al. 2017).

The carbon content in plant tissues is commonly ca. $50 \%$ on a dry mass basis, although it varies

PeerJ reviewing PDF | (2019:10:41903:2:1:NEW 29 Apr 2020) 
215 depending on different factors, such as the developmental stage, organ, species, latitude, water 216 availability, nutrient availability, and the $\mathrm{CO}_{2}$ concentration prevalent during organ development (Díaz217 Álvarez et al., 2015; Ma et al., 2018). High $\mathrm{CO}_{2}$ concentrations, such as those found in urban 218 environments, like Mexico City, are among the factors leading to higher photosynthetic rates in CAM 219 plants (Drennan and Nobel, 2000; Andrade et al., 2007; Smith et al., 2009; Zotz et al., 2010; SEDEMA, 220 2016a). However, when plants are exposed to different concentrations of hazardous gases such as NOx, $221 \mathrm{SO}_{2}$ and, $\mathrm{CO}$, the net photosynthetic rate and the photosynthetic pigment content can decrease, because 222 the resulting oxidative stress alters the carboxylation process, leading to a net reduction of the carbon 223 content (Bytnerowicz et al., 2001; Mittler, 2002; Muneer et al., 2014). Such gases are monitored and have 224 actually been detected in areas of Mexico City and Pachuca, although it appears that their concentration is 225 not high enough to cause a tissue carbon reduction for Tillandsia recurvata (Díaz-Álvarez and de la

226 227 228 229 230 231 232 233 234 235 236 237 238 239 Barrera 2018; SEDEMA, 2016a). In this respect, this species displays a physiological resistance to $\mathrm{O}_{3}$ and $\mathrm{SO}_{2}$, which may contribute to the results observed (Benzig et al., 1992).

Three factors can help explain the general carbon isotopic pattern observed for T. recurvata throughout the study. The first factor is a large difference in the isotopic signature for $\mathrm{CO}_{2}$ from different sources. In particular, the $\delta^{13} \mathrm{C}$ values of the air from natural environments can reach $-8 \%$ (Pichlmayer et al., 1998; Widory \& Javoy, 2003). In contrast, the carbon in the air is depleted of ${ }^{13} \mathrm{C}$ in sites where motor vehicles and the industrial activities are common. In this regard, the $\delta^{13} \mathrm{C}$ values for coal burning, gasoline, diesel, and natural gas range from -25 to $-42 \%$ (Pichlmayer et al., 1998; Röckman et al., 2002; Pataki et al., 2003; Widory \& Javoy, 2003; Semmens et al., 2004; Naus et al., 2018).

A second factor is an increasing isotopic discrimination against ${ }^{13} \mathrm{C}$ that occurs for CAM plants exposed to high $\mathrm{CO}_{2}$ concentrations (Zhu et al., 1999). In this case, given that increasing concentrations of $\mathrm{CO}_{2}$ can inhibit the activity of phosphoenolpyruvate carboxylase (PEPc), which is already near saturation at natural concentrations of $\mathrm{CO}_{2}$ (Ting, 1994). PEPc has an isotopic discrimination that ranges between 2 and $10 \%$, which explains the common $\partial^{13} \mathrm{C}$ values for CAM plants. However, if PEPc is inhibited, the ribulose bisphosphate carboxylase/oxygenase, an enzyme with a higher discrimination of 
$24122-27 \%$, will conduct most of the carboxylation, resulting in the observed $\partial^{13} \mathrm{C}$ values, which were more 242 negative in polluted sites (Ehleringer \& Osmod, 1989; Farquhar et al., 1989; Ting 1994; McNevin et al., 243 2007; Smith et al., 2009; Cernusak et al., 2013).

244 A third potential factor influencing the observed pattern is air temperature in cities. Warmer than 245 natural nocturnal air temperatures, such as those resulting from the urban heat island in Mexico city, drive 246 changes in the carbon fixation cycle of CAM plants, which in turn leads to an increased isotopic 247 discrimination against ${ }^{13} \mathrm{C}$ (Troughton \& Card, 1975; Farquhar et al., 1989; Jauregui, 1997; Zhu et al., 248 1999; Cui \& de Foy, 2012; Cernusak et al., 2013).

249

250

251

252

253

254

255

256

257 258

259

260

261

262

263

264

265

266

267

268

\section{Conclusions}

Owing to the close relationship observed between the isotopic composition of Tillandsia recurvata and the atmospheric CO concentration in the Valley of Mexico, the $\delta^{13} \mathrm{C}$ values can be useful for characterizing carbonaceous pollution. In addition, given that the emissions of $\mathrm{CO}$ and $\mathrm{CO}_{2}$ are accompanied by the emission of other pollutants, such as $\mathrm{NOx}, \mathrm{SO}^{2}$, and heavy metals, which results in the formation of secondary pollutants such as $\mathrm{O}_{3}$ and particulate matter, this plant can be deemed as an ideal candidate for implementing broader monitoring studies in regions where automatic monitoring networks are not available and the bromeliad is abundant.

\section{Acknowledgements}

We thank funding by the Dirección General de Asuntos del Personal Académico, Universidad Nacional Autónoma de México (PAPIIT IN205616 and IN211519). We also thank Mr. F.S. Zúñiga for his hospitality in Mexico City and the generosity of the personnel of the Zona Arqueológica de Teotihuacán, especially Dr. V. Ortega. 


\section{References}

270 Andrade JL, de la Barrera E, Reyes-García C, Ricalde MF, Vargas-Soto G, Cervera JC (2007) El

271 Metabolismo ácido de las crasuláceas diversidad, fisiología ambiental y productividad. Bol $272 \quad$ Soc Bot México 81:37-51.

273 Benzing, D. H., Arditti, J., Nyman, L. P., Temple, P. J., \& Bennett, J. P. (1992). Effects of ozone 274 and sulfur dioxide on four epiphytic bromeliads. Environmental and Experimental Botany, 275 32(1), 25-32. doi:10.1016/0098-8472(92)90026-x

276

277

278

279

280

281

282

283

284

285

286

287

288

289

290

291

292

Bytnerowicz, A., Padgett, P.E., Parry, S.D., Fenn, M.E., Arbaugh, M.J., 2001. Concentrations, deposition, and effects of nitrogenous pollutants in selected California ecosystems. Sci. World J. 1, 304e311. Doi: 10.1100/tsw.2001.395.

Calderón, R. G., Rzedowski, J. Flora fanerógamica del Valle de México. pp.1406. (Instituto de Ecología y CONABIO, Xalapa, Veracruz, México 2001).

Castañeda Miranda, A. G., Chaparro, M. A. E., Chaparro, M. A. E., \& Böhnel, H. N. (2016). Magnetic properties of Tillandsia recurvata L. and its use for biomonitoring a Mexican metropolitan area. Ecological Indicators, 60, 125-136. doi:10.1016/j.ecolind.2015.06.025

Cernusak, L. A., Ubierna, N., Winter, K., Holtum, J. A. M., Marshall, J. D., \& Farquhar, G. D. (2013). Environmental and physiological determinants of carbon isotope discrimination in terrestrial plants. New Phytologist, 200(4), 950-965. doi:10.1111/nph.12423

Chen TM, Kushner WG, Gokhale J, Shofer S. 2007. Outdoor air pollution: nitrogen dioxide, sulfur dioxide, and carbon monoxide health effects. Am. J. Med. Sci. 333, 249-256.

Cobley, L.A.E., \& Pataki, D. E. (2019). Vehicle emissions and fertilizer impact the leaf chemistry of urban trees in Salt Lake Valley, UT. Environmental Pollution, 254, 112984. doi:10.1016/j.envpol.2019.112984

Cressie, N. 1988. Spatial prediction and ordinary Kriging. Math. Geol 20, 405-421. 
293 Cui, Y. Y., \& de Foy, B. (2012). Seasonal Variations of the Urban Heat Island at the Surface and the 294 Near-Surface and Reductions due to Urban Vegetation in Mexico City. Journal of Applied 295 Meteorology and Climatology, 51(5), 855-868. Doi: 10.1175/jamc-d-11-0104.1

296 Díaz-Álvarez E.A., de la Barrera E. 2018. Characterization of nitrogen deposition in a megalopolis by 297 means of atmospheric biomonitors. Scientific Reports, 8:13569. Doi: 10.1038/s41598-018-32000$298 \quad 5$

299 Díaz-Álvarez E.A. Lindig-Cisneros R, de la Barrera E. 2015. Responses to simulated nitrogen deposition $300 \quad$ by the neotropical epiphytic orchid Laelia speciosa. PeerJ 3: e1021.

301 Díaz-Álvarez, E. A., Lindig-Cisneros, R. de la Barrera, E. 2018. Biomonitors of atmospheric nitrogen 302 deposition: potential uses and limitations. Conserv. Physiol. Conserv 6, coy011. Doi: 10.1093/conphys/coy011

304

305

306

307

308

309

310

Díaz-Álvarez E. A., de la Barrera, E., Arciga-Pedraza A. Arróniz-Crespo M. 2019. Bryophyte enzymatic responses to atmospheric nitrogen deposition: A field validation for potential biomonitors. The Bryologist. 122: 396-403. Doi: 10.1639/0007-2745-122.3.396.

Díaz-Álvarez EA, de la Barrera E, Barrios-Hernández EY, Arróniz-Crespo M. 2020. Morphophysiological screening of potential organisms for biomonitoring nitrogen deposition. Ecological Indicators 108: 105729. DOI: 10.1016/j.ecolind.2019.105729

Drennan P.M. Nobel P.S. 2000. Responses of CAM species to increasing atmospheric CO2 concentrations. Plant Cell and Environment. 23: 767-781.

Ehleringer, J. R., Osmond, B. O. 1989. Stable isotopes. Plant physiological ecology. (ed. Pearcy, R. W., Ehleringer, J. R., Mooney, H. A., Rundel, P. W.) 281-300 (Chapman \& Hall, 1989).

Evans R. 2001. Physiological mechanisms influencing plant nitrogen isotope composition. Trends Plant Sci 6:121-126.

Farquhar, G. D., Ehleringer, J. R., \& Hubick, K. T. (1989). Carbon Isotope Discrimination and Photosynthesis. Annual Review of Plant Physiology and Plant Molecular Biology, 40(1), 503-537. Doi:10.1146/annurev.pp.40.060189.0024 
319 Gómez-Losada A, Santos FM, Gibert K, Pires JCM. 2019. A data science approach for spatio

320

321

322

323

324

325

326

327

328

329

330

331

332

333

334

335

336

337

338

339

340

341 temporal modelling of low and resident air pollution in Madrid (Spain): Implications for epidemiological studies. Computers, Environment and Urban sysems 75: 1-11. DOI: 10.1016/j.compenvurbsys.2018.s12.005

Gromov S, Nrenninkmeije CAM, Jöckel P. 2017. Proxies and uncertainties for 13C/12C ratios of atmospheric reactive gases emissions. Atmospheric Chemistry and Physics Discussions 17: doi:10.5194/acp-2016-1138

Gupta S, Pebesma E, Mateu J, Degbelo A. 2018. Air quality monitoring network design optimisation for robust land use regression models. Sustainability 10: 1442. DOI: $10.3390 / \mathrm{su} 10051442$

Harmens D, Norris D, Cooper D, Hall J. 2008. Spatial trends in nitrogen concentrations in mosses agross Europe in 2005/2006. Report on Nitrogen in European Mosses Work Package 4. The UNECE International Cooperative Program on Vegetation, https://icpvegetation.ceh.ac.uk/

Hooper, D. U., Adair, E. C., Cardinale, B. J., Byrnes, J. E. K., Hungate, B. A., Matulich, K. L., O’Connor, M. I. (2012). A global synthesis reveals biodiversity loss as a major driver of ecosystem change. Nature, 486(7401), 105-108. doi:10.1038/nature11118

Huang S, Xiang H, Yang W, Zhu Z, Tian L, Deng S, Zhang T, Lu Y, Liu F, Li X, Liu S. 2020. Short-term effect of air pollution on tuberculosis based on Kriged data: a time-series analysis. International Journal of Environmental Research and Public Health 17: 1522. DOI: $10.3390 /$ ijerph17051522

Instituto Nacional de Ecología y Cambio Climático (INECC). 2017. Informe Nacional de Calidad del Aire 2016, México. 
342 Instituto Nacional de Estadística y Geografía (INEGI). 2011. Censo de población y vivienda 2010.

$343 \quad$ Available at:

344 http://web.archive.org/web/20120505010044/http:/www.censo2010.org.mx/doc/cpv10p_pres.pdf

$345 \quad$. Accessed September 6th 2016.

346 Jauregui, E. (1997). Heat island development in Mexico City. Atmospheric Environment, 31(22), 3821-

347 3831. Doi: 10.1016/s1352-2310(97)00136-2

348 Kampa, M., \& Castanas, E. (2008). Human health effects of air pollution. Environmental Pollution,

349 151(2), 362-367. doi:10.1016/j.envpol.2007.06.012

350 Liao Y, Li D, Zhang N. 2017. Comparison of interpolation models for estimating heavy metals in soils

351 under various spatial characteristics and sampling methods. Transactions in GIS 22: 409-434.

352 DOI: $10.1111 /$ tgis. 12319

353 Lichtfouse E, Lichtfouse M, Jaffrézic A. 2003. $\partial^{13} \mathrm{C}$ values of grasses as a novel indicator of pollution by

354

355

fosil-fuel-derived greenhouse gas $\mathrm{CO}_{2}$ in urban areas. Environmental Science and Technology 37:

356 $87-89$.

Ma, S., He, F., Tian, D., Zou, D., Yan, Z., Yang, Y., Zhou T., Huang K., Shen H., Fang, J. (2018).

357 Variations and determinants of carbon content in plants: a global synthesis. Biogeosciences, 15:

358 693-702. Doi: 10.5194/bg-15-693-2018

359

360

361

362

Markert, B.A., Breure, A.M., Zechmeister, H.G. 2003. Definitions, strategies and principles for bioindication/biomonitoring of the environment. In: Markert, B.A., Breure, A.M., Zechmeister, H.G. (eds.) Bioindicators and Biomonitors: Principles, Concepts and Applications. Elsevier, Oxfort. Pp. 3-40.

Martin, C. E. 1994. Physiological ecology of the Bromeliaceae, Bot. Rev., 60(1), 1-82.

McNevin, D. B., Badger, M. R., Whitney, S. M., von Caemmerer, S., Tcherkez, G. G. B., \& Farquhar, G. D. (2007). Differences in Carbon Isotope Discrimination of Three Variants of D-Ribulose-1,5bisphosphate Carboxylase/Oxygenase Reflect Differences in Their Catalytic Mechanisms. Journal of Biological Chemistry, 282(49), 36068-36076. doi:10.1074/jbc.m706274200 
368 Mittler R (2002). Oxidative stress, antioxidants and stress tolerance. Trends Plant Sci.7: 405-410.

369 Muneer, S., Kim, T. H., Choi, B. C., Lee, B. S., Lee, J. H. (2014). Effect of CO, NOx and $\mathrm{SO}_{2}$ on ROS 370 production, photosynthesis andascorbate-glutathione pathway to induce Fragaria $\times$ annasa as a 371 hyperaccumulator. Redox Biology. 2: 91-98. DOI: 10.1016/j.redox.2013.12.006

372 Naus, S., Röckmann, T., Popa, M. E. (2018). The isotopic composition of CO in vehicle exhaust. $373 \quad$ Atmospheric Environment, 177, 132-142. doi:10.1016/j.atmosenv.2018.01.015

374 Oliver MA, Webster R. 2014. A tutorial guide to geostatistics: Computing and modelling variograms and $375 \quad$ kriging. Catena 113: 56-69. DOI: 10.1016/j.catena.2013.09.006

376 Pataki DE, Bowling DR, Ehleringer JR. 2003. Seasonal cycle of carbon dioxide and its isotopic 377 composition in an urban atmosphere: Anthropogenic and biogenic effects. Journal of geophysical 378 research. 108. D23, 4735. Doi: 10.1029/2003JD003865.

379

380

381

382

383

384

385

386

387

388 389

390

391

392

Pellegrini E, Lorenzini G, Loppi S, Nali C. 2014. Evaluation of the suitability of Tillandsia usneoides (L.) L. as biomonitor of airborne elements in an urban area of Italy, Mediterranean basin. Atmospheric Pollution Research 5: 226-235.

Piazzetta, K.D., Ramsdorf, W.A. \& Maranho, L.T. (2018) Use of airplant Tillandsia recurvata L., Bromeliaceae, as biomonitor of urban air pollution. Aerobiologia, 35: 125. Doi: 10.1007/s10453$\underline{018-9545-3}$

Pichlmayer, F., Schoner, W., Seibert, P., Stichler, W., Wagen-bach, D. 1998: Stable isotope analysis for characterization of pollutants at high elevation alpine sites, Atmos. Environ., 32(23), 4075-4085, 1998

Pohlert T. (2014). The Pairwise Multiple Comparison of Mean Ranks Package (PMCMR). R package. http://CRAN.R-project.org/package=PMCMR.

Prockop LD. 2005. Carbon monoxide brain toxicity: clinical, magnetic resonance imaging, magnetic resonance spectroscopy, and neuropsychological effects in 9 people. J. Neuroimaging 15, 144149. 
393 Rioja-Rodríguez H., Soares da Silva A., Texcala-Sangrador JL., Moreno-Banda GL. 2016 Air pollution

394

395

396

397

398

399

400

401

402

403

404

405

406

407

408

409

410

411

412

413

414

415

416

417

418 management and control in Latin America and the Caribbean: implications for climate change. Rev Panam Salud Publica. 2016;40(3):150-59.

Röckmann T, Jöckel P, Gros V, Bräunlich M, Possne G. Brenninkmeijer CAM. 2002. Using ${ }^{14} \mathrm{C},{ }^{13} \mathrm{C},{ }^{18} \mathrm{O}$ and ${ }^{17} \mathrm{O}$ isotopic variations to provide insights into the high northern latitude surface $\mathrm{CO}$ inventory. Atmospheric Chemistry and Physics, 2(2):147-159, 2002.

Rockström, J., W. Steffen, K. Noone, Å. Persson, F. S. Chapin, III, E. Lambin, T. M. Lenton, M. Scheffer, C. Folke, H. Schellnhuber, B. Nykvist, C. A. De Wit, T. Hughes, S. van der Leeuw, H. Rodhe, S. Sörlin, P. K. Snyder, R. Costanza, U. Svedin, M. Falkenmark, L. Karlberg, R. W. Corell, V. J. Fabry, J. Hansen, B. Walker, D. Liverman, K. Richardson, P. Crutzen, and J. Foley. 2009. Planetary boundaries:exploring the safe operating space for humanity. Ecology and Society 14(2): 32 .

Sala OE, Chapin III SF, Armesto JJ, Berlow E, Bloomfield J, Dirzo R, Huber-Sanwald E, Huenneke LF, Jackson RB, Kinzig A, Leemans R, Lodge DM, Mooney HA, Oesterheld M, Poff NL, Sykes MT, Walker BH, Walker M, Wal DH (2000) Global biodiversity scenarios for the year 2100. Science 287:1770-1774. doi: 10.1126/science.287.5459.1770.

Salameh, Z. (2014). Factors Promoting Renewable Energy Applications. Renewable Energy System Design, 1-32. doi:10.1016/b978-0-12-374991-8.00001-5

Schmitt, A. K., Martin, C. E., and Luttge, U. E.: Gas exchange "and water vapor uptake in the atmospheric bromeliad Tillandsia recurvata L, Bot. Acta, 102, 80-84, 1989.

Schrimpff, E. (1984). Air pollution patterns in two cities of Colombia, S. A. According to trace substances content of an epiphyte (Tillandsia recurvata L.). Water, Air, and Soil Pollution, 21(14), 279-315. doi:10.1007/bf00163631

SEDEMA, Secretaría del Medio Ambiente de la Ciudad de México. 2016a. Inventario de emisiones de la CDMX, contaminantes criterio, tóxicos y de efecto invernadero 2014. Dirección General de Gestión de la Calidad del Aire, Dirección de Monitoreo Atmosférico. México, D. F. 
419 SEDEMA, Secretaría del Medio Ambiente de la Ciudad de México. 2016b. Calidad del aire en la Ciudad

420

421

422

423

424 425

426

427

428

429

430

431

432

433

434

435

436

437

438

439

440

441

442

443

de México, informe 2015. Dirección General de Gestión de la Calidad del Aire, Dirección de Monitoreo Atmosférico. México, D. F.

SEMARNAT 2012. Norma Oficial Mexicana NOM-156-SEMARNAT-2012, Establecimiento y operación de sistemas de monitoreo de la calidad del aire. México D.F.

Semmens C, Ketler R, Schwendenmann L, Nesic Z, Christen A. 2014. Isotopic composition of CO2 in gasoline, diesel and natural gas combustion exhaust in Vancouver, BC, Canada. A technical report of the University of British Columbia. pp. 1-12. Doi: $\quad 10.14288 / 1.0103591$

Servicio Meteorológico Nacional (SMN). Normales climatológicas por estado 1981-2010. http://smn.cna.gob.mx/es/informacion-climatologica-ver-estado?estado=df. http://smn.cna.gob.mx/es/informacion-climatologica-ver-estado?estado=gto. http://smn.cna.gob.mx/es/informacion-climatologica-ver-estado?estado=mex (2016).

Silva, S. J., Arellano, A. F., \& Worden, H. M. (2013). Toward anthropogenic combustion emission constraints from space-based analysis of urban $\mathrm{CO} 2$ /CO sensitivity. Geophysical Research Letters, 40(18), 4971-4976. doi:10.1002/grl.50954

Smith SD, Tissue DT, Huxman TE, Loik ME. 2009. Ecophysiological responses of desert plants to elevated CO2: environmental determinants and case studies. In: de la Barrera E, Smith WK (eds.) Perspectives in Biophysical Plant Ecophysiology: A Tribute to Park S. Nobel. UNAM, Mexico City. Pp. 363-390.

Stevens CJ, Dise NB, Mountford JO, Gowing DJ. 2004. Impact of nitrogen deposition on the species richness of grasslands. Science 303: 1876-1879. DOI: 10.1126/science.1094678.

Stevens G, Dias RH, Thomas KJA, Rivera JA, Carvalho N, Barquera S. Hill K. Ezzati M. 2008. Characterizing the Epidemiological Transition in Mexico: National and Subnational Burden of Diseases, Injuries, and Risk Factors. PLOS Medicine 5(7): e163. Doi: 10.1371/journal.pmed.0050163 
444 Ting I.P. (1994) CO2 and Crassulacean acid metabolism plants: a review. In Regulation of Atmospheric 445 CO2and O2 by Photosynthetic Carbon Metabolism (eds N.E. Tolbert \& J.Preiss), pp. 176446 183, Oxford University Press, Oxford.

447 Townsend CL, Maynard RL. 2002. Effects on health of prolonged exposure to low concentrations of $448 \quad$ carbon monoxide. Occup. Environ. Med. 59, 708-711.

449 Troughton, J. H., \& Card, K. A. (1975). Temperature effects on the carbon-isotope ratio of C3, C4 and 450 crassulacean-acid-metabolism (CAM) plants. Planta, 123(2), 185-190. doi:10.1007/bf00383867

451 Turnbull JC, Karion A, Fischer ML, Faloona I, Guilderson T, Lehman SJ, Miller BR, Miller JB, Montzka 452 S, Sherwood T, Saripalli S, Sweeney C, Tans PP. 2011a. Assessment of fossil fuel carbon dioxide and other anthropogenic gas emissions from airborne measurements over Sacrmento, California

455

456

457

458

459

460

461

462

463

464

465

466

467

468 in spring 2009. Atmospheric Chemistry and Physics 11: 705-721.

Turnbull, J. C., Tans, P. P., Lehman, S. J., Baker, D., Conway, T. J., Chung, Y. S., ... Zhou, L.-X. 2011 b. Atmospheric observations of carbon monoxide and fossil fuel $\mathrm{CO} 2$ emissions from East Asia. Journal of Geophysical Research: Atmospheres, 116(D24), n/a-n/a. doi:10.1029/2011jd016691

Vianna NA, Gonçalves D, Brandao F, de Barros RP, Amado Filho GM, Meire RO, Torres JP, Malm O, D'Oliveira Júnior A, Andrade LR. 2011. Assessment of heavy metals in the particulate matter of two Brazilian metropolitan areas by using Tillandsia usneoides as atmospheric biomonitor. Environmental Science and Pollution Research International 18: 416-427. DOI: 10.1007/s11356$010-0387-y$

Wang J, Liu J, Zhuan D, Li L, Ge Y. 2002. Spatial sampling design for monitoring the area of cultivated land. International Journal of Remote Sensing 23: 263-284. DOI: 10.1080/01431160010025998

Wang W, Pataki DE 2010. Spatial patterns of plant isotope tracers in the Los Angeles urban region. Landsc Ecol 25:35-52.

Widory D., Javoy M. (2003). The carbon isotope composition of atmospheric CO 2 in Paris. Earth and Planetary Science Letters, 215(1-2), 289-298. Doi:10.1016/s0012-821x(03)00397-2 
469 Williams, A. (1990). Pollutant formation and control. Combustion of Liquid Fuel Sprays, 127-160.

470 doi:10.1016/b978-0-408-04113-3.50009-9

471 Wong DW, Yuan L, Perlin SA. 2004. Comparison of spatial interpolation methods for the estimation of 472 air quality data. Journal of Exposure Analysis and Environmental Epidemiology 14: 404-415.

473 DOI: $10.1038 /$ sj.jea. 7500338

474 World Health Organization WHO 1999. Environmental Health Criteria 213, Carbon monoxide (second 475 edition). Geneva, Pp. 464

476 Zambrano A, Medina C, Rojas A, López D, Chang L, Sosa G (2009) Distribution and sources of 477 bioaccumulative air pollutants at Mezquital Valley, Mexico, as reflected by the 478 atmospheric plant Tillandsia recurvata L. Atmos Chem Phys 9:6479-6494.

479 Zhu J., Goldstein G. \& Bartholomew D.P. (1999) Gas exchange andcarbon isotope composition 480 of Ananas comosusin response toelevated CO2and temperature. Plant, Cell and $481 \quad$ Environment22, 999-1007.

482 Zotz G, Wiebke B, Hietz P, Nadine K (2010) Growth of epiphytic bromeliads in a changing 483 world: The effects of $\mathrm{CO}_{2}$, water and nutrient supply. Acta Oecol 36:659-665. Doi:

$484 \quad 10.1016 /$ j.actao.2010.10.003 


\section{Figure 1}

Region in central Mexico where the study was conducted.

Location of the Valley of Mexico (blue polygon) in Mexico (A). Spatial distribution of the collecting sites throughout the Valley represented by the red squares. The stations belonging to the automatic monitoring network are indicated by yellow dots (B). This network is located between Mexico City and the State of Mexico in the most populated zone of the region. 


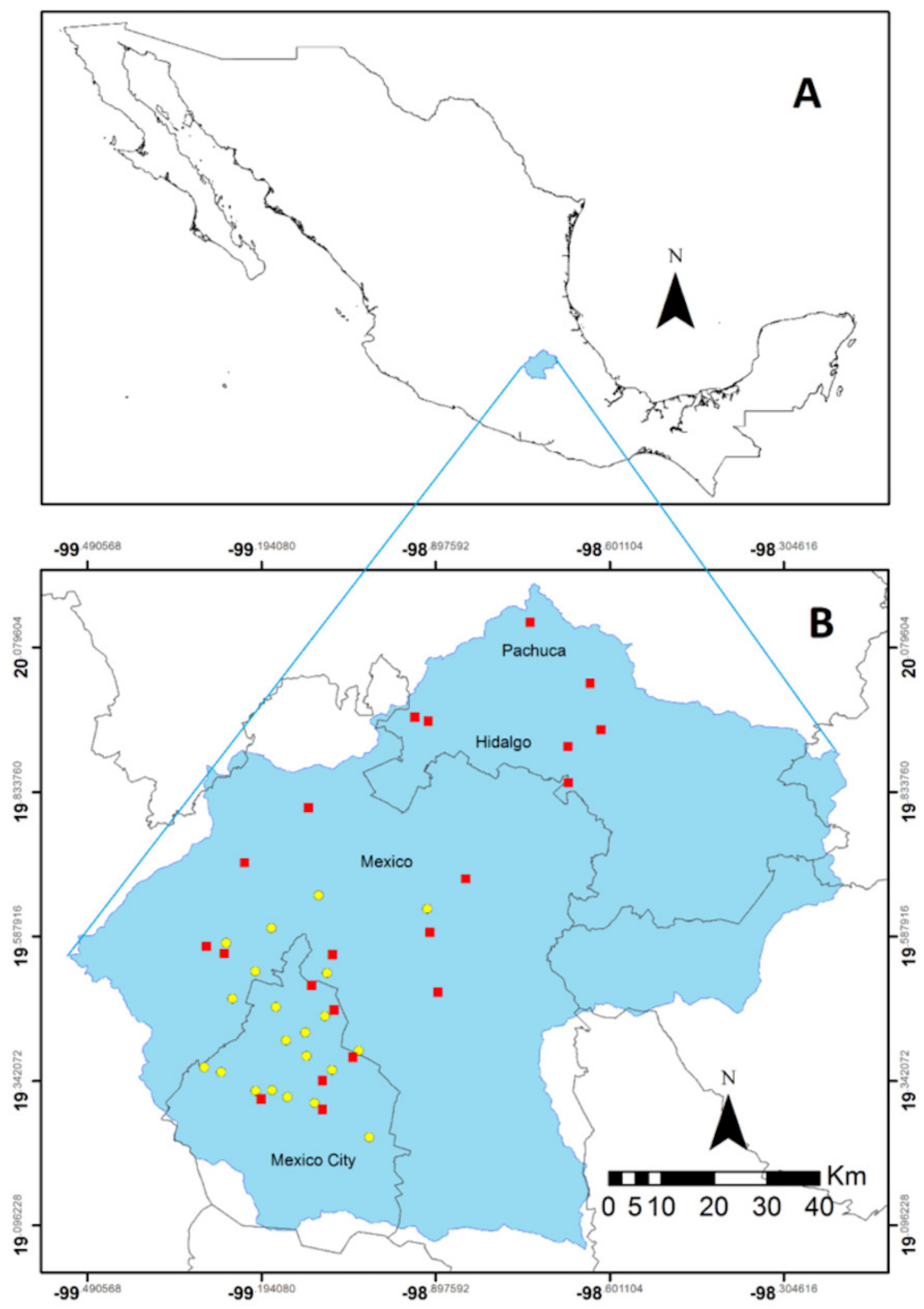


Figure 2

Carbon monoxide concentrations in Mexico City

Ordinary kriging for the carbon monoxide concentrations, in parts per million, inside the area covered by the air quality network in the Valley. The data consisted of mean concentration of CO during the period that comprises January to November 2014. The data utilized for this analysis are available at http://www.aire.cdmx.gob.mx .

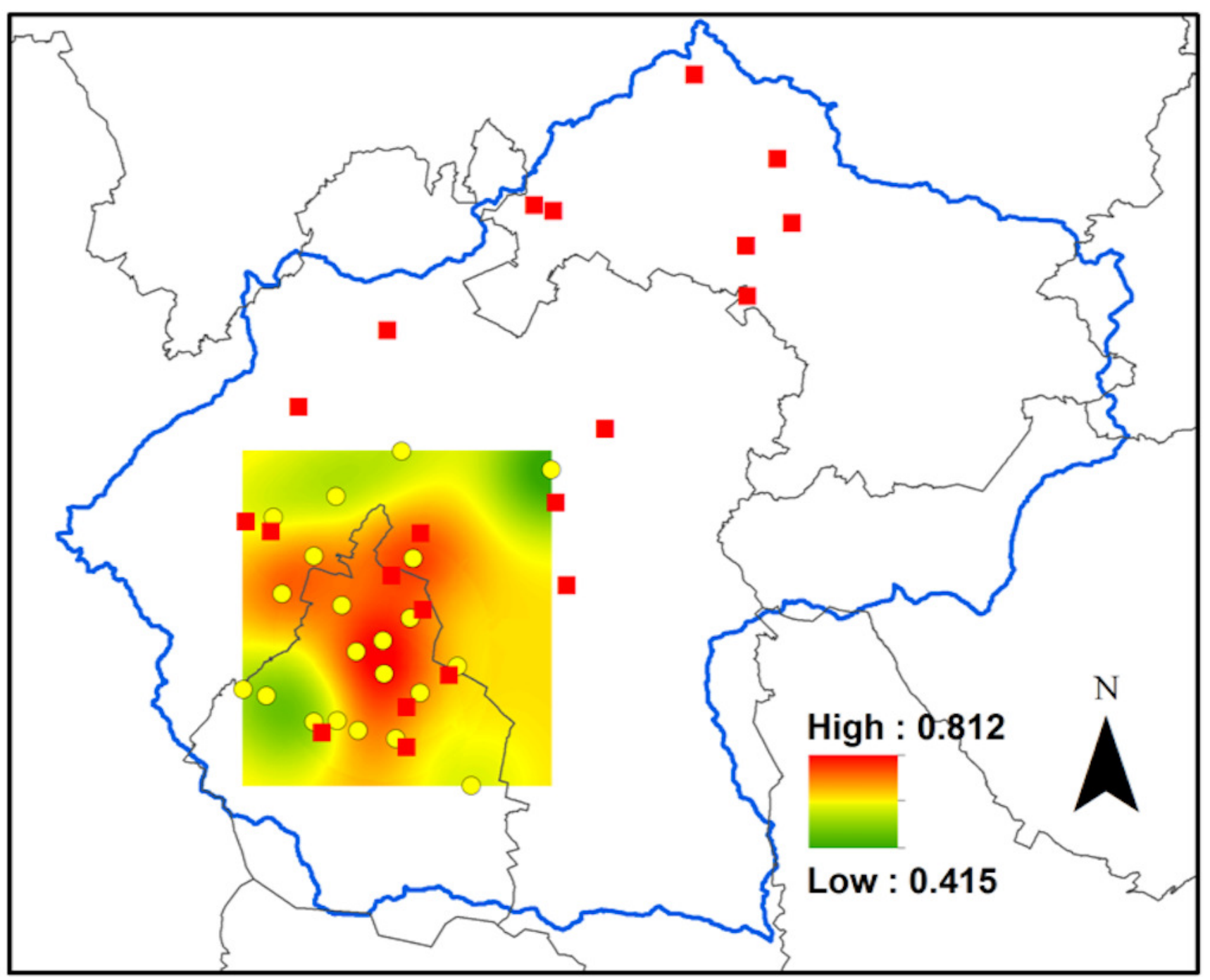


Figure 3

Biomonitor carbon status in the Mexico valley

Ordinary kriging for the carbon content (A) and $\delta^{13} \mathrm{C}$ values (B) for Tillandsia recurvata in the Valley of Mexico. 


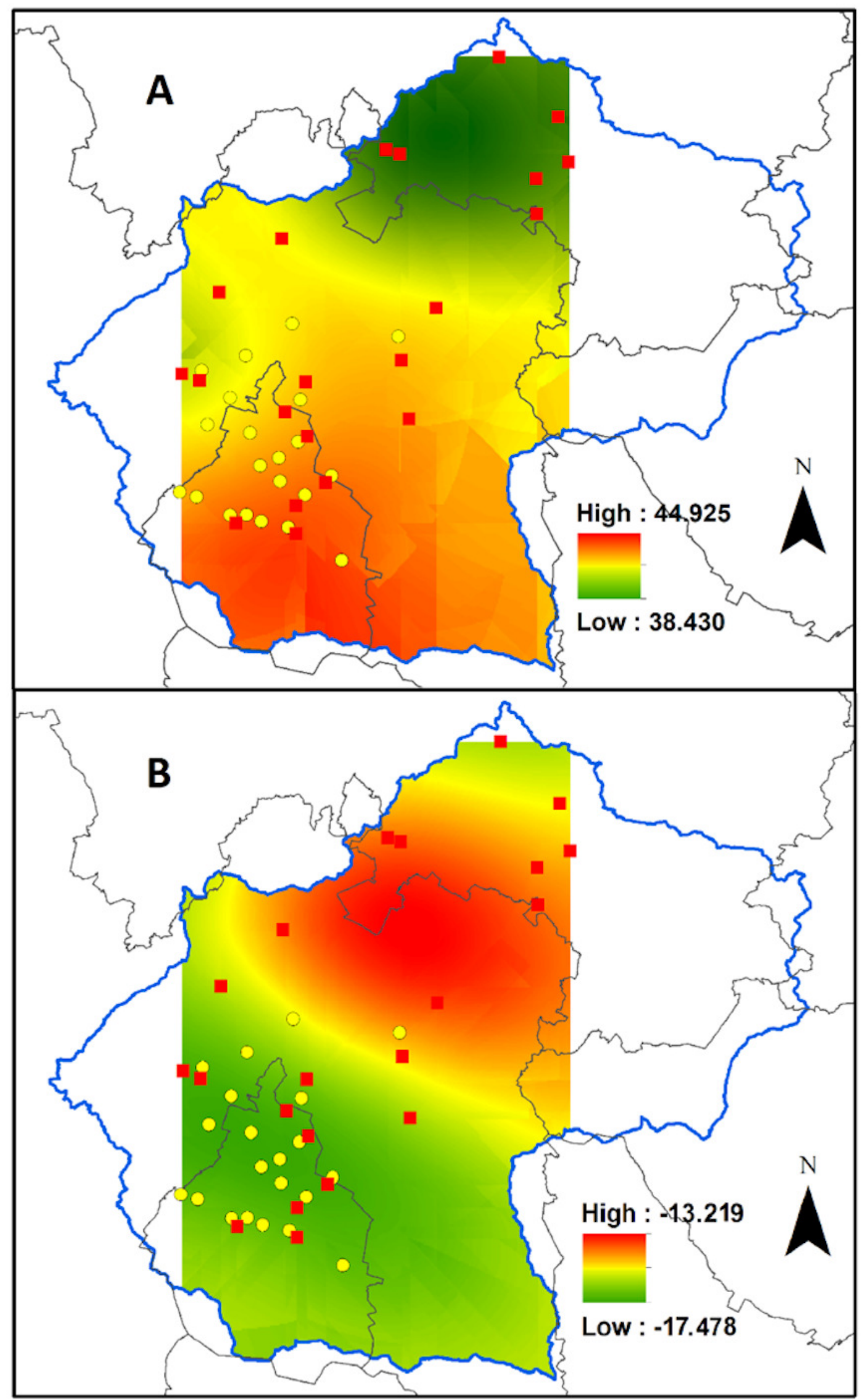


Figure 4

Biomonitor responses to carbon monoxide

Linear regression for the relationship between CO concentration in ppm during 2014 and the carbon content (A), and the $\delta^{13} \mathrm{C}$ values (B) for Tillandsia recurvata at the Valley of Mexico ( $\mathrm{n}$ $=5)$. 


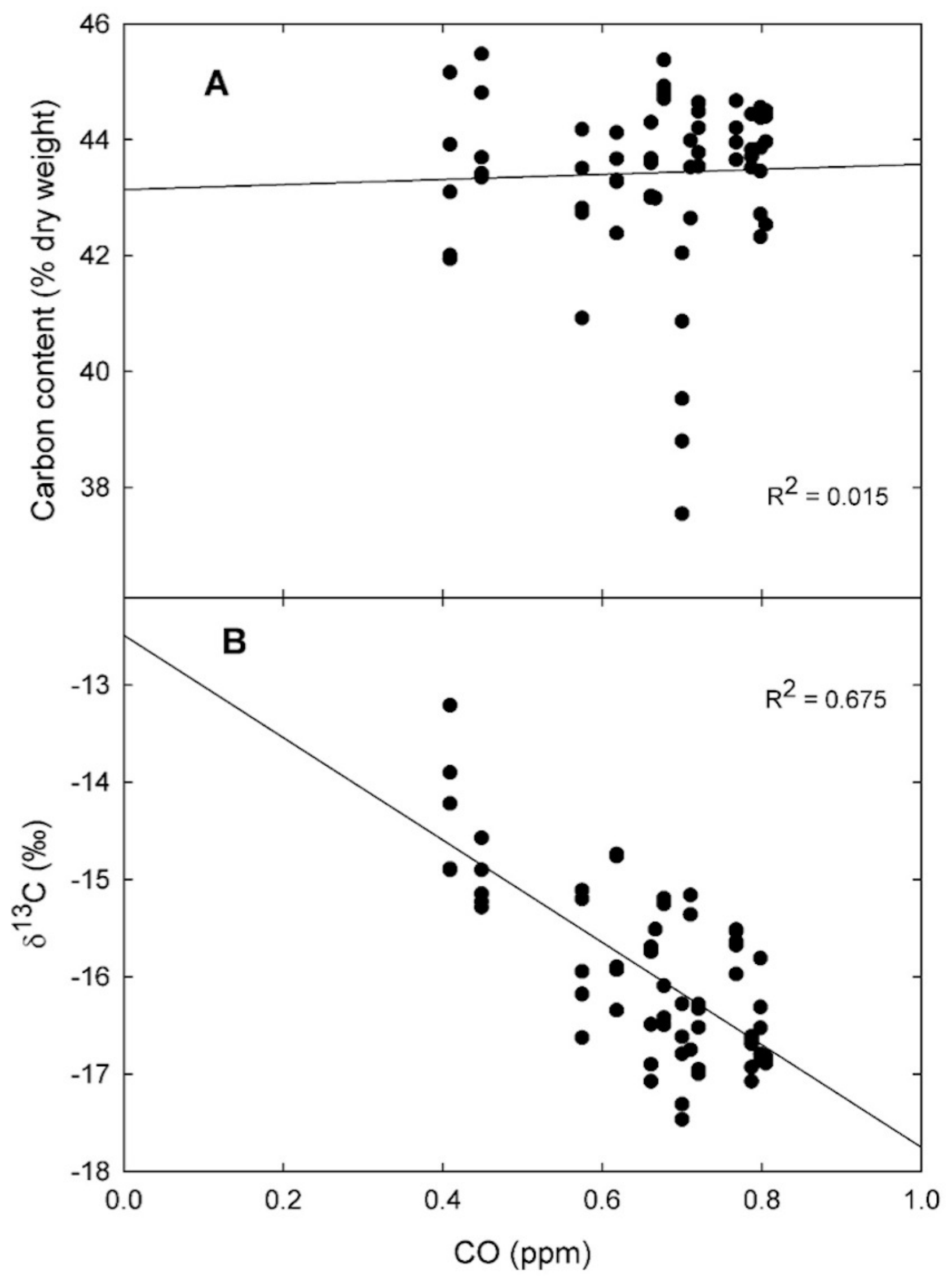

